\title{
INSTITUIÇÕES CONTEMPORÂNEAS DE EDUCAÇÃO FORMAL: UMA ANÁLISE DA ARQUITETURA ESCOLAR
}

\author{
Victória Louise de Paula Santos Carminatti ${ }^{\mathrm{i}}$ \\ Patrícia Gräff ${ }^{\mathrm{ii}}$
}

\begin{abstract}
Resumo: O artigo se propõe a analisar a arquitetura de diferentes espaços escolares (Educação Básica e Educação Superior). Metodologicamente, utilizou-se da fotografia como instrumento para a produção de dados, na organização de um estudo qualitativo que teve nos Estudos Foucaultianos seu ancoradouro teórico. Partindo das imagens capturadas de seis instituições escolares, foram identificadas as características principais que compõem a arquitetura em cada nível escolar. Os resultados mostraram que a arquitetura escolar está constituída em um modelo pensado no século XVII, com políticas que se voltam para a segurança, mas também para a vigilância, produzindo, através da hierarquia, da economia do tempo, da organização, da observação e do silêncio, uma sociedade disciplinar.
\end{abstract}

Palavras-chave: Educação; Instituições de ensino; Políticas Educacionais.

\section{CONTEMPORARY INSTITUTIONS OF FORMAL EDUCATION: AN ANALYSIS OF SCHOOL ARCHITECTURE}

Abstract: This article aims to search for approximations and distances between the architecture of different school spaces (Basic Education and Higher Education). Methodologically, photography was used as instrument of data production, in organizing a qualitative study which had in Foucaultian Studies its theoretical anchorage. Starting from the captured images of six school institutions, have been identified the main features that make up the architecture in each school level. The results found showed that the school architecture is constituted in a model thought in the 17th century, with politics that focus on security, but also for the surveillance, producing, through the hierarchy, of time savings, of organization, of observation and silence, a disciplinary society.

Keywords: Education; Educational institutions; Educational Policies.

\section{Introdução}

Michel Foucault dedicou parte de seus estudos ao exercício do poder, indicando que não existe apenas um poder, mas sim poderes e contra-poderes que estão difundidos na sociedade (FOUCAULT, 2013). Nessa direção, passamos a compreender a escola, sua arquitetura e organização como parte de um conjunto de estratégias que visa o disciplinamento dos corpos, na construção do que Foucault (1987, p. 119) chama de "arte do corpo humano", que torna o corpo "mais obediente" e "mais útil". Sob essa perspectiva, Michel Foucault (1987) apresenta as noções de poder, disciplina e poder disciplinar, conceitos 
imprescindíveis para compreender o modo como as instituições de educação disciplinam os corpos, por meio de sua organização.

Com o objetivo de compreender como as escolas estão configuradas e como o espaço escolar exerce poder disciplinar sobre os corpos dos escolares, realizamos um estudo qualitativo visitando instituições formais de educação do município de Chapecó-SC. Procuramos, ainda, entender como as estruturas arquitetônicas se organizam; compreender a relação entre a legislação nacional sobre a Educação e as estruturas arquitetônicas dos espaços de educação formal; e, por fim, compreender como são organizados os espaços destinados ao lazer dos estudantes e o potencial disciplinar desses espaços de educação formal. Visando compreender e problematizar a sua organização, na Contemporaneidade, dividimos este texto em duas partes: 1) metodologia - que apresenta o percurso metodológico da pesquisa - e, 2) análises $e$ discussões - que traz os dados da pesquisa cotejados a partir de um conjunto de teorizações atuais que toma a arquitetura escolar como foco central. Por fim, trazemos as considerações finais do texto.

\section{Metodologia}

Esta pesquisa se caracteriza a partir de uma perspectiva qualitativa, filiada ao campo dos Estudos Foucaultianos em Educação. A pesquisa de campo ocorreu no município de Chapecó-SC, por meio de registros fotográficos sobre a arquitetura de seis instituições de educação formal. As fotografias produzidas nos espaços escolares vazios serviram como documento analítico, como textos não verbais que materializam a organização arquitetônica das instituições estudadas. Para a pesquisa, foram escolhidas duas instituições públicas de cada etapa da escolarização, de modo a ampliar as possibilidades de leitura sobre a arquitetura escolar da Educação Infantil ao Ensino Superior. Ao longo das análises e discussões elas se encontram nominadas como: Educação Infantil (EI1 e EI2); Ensino Fundamental (EF1 e EF2), e; Ensino Superior (ES1 e ES2).

Para a operacionalização da pesquisa de campo, enviamos um documento a cada uma das instituições, solicitando autorização para fotografar e pesquisar as suas estruturas arquitetônicas. A partir de agendamento de datas com cada instituição, fizemos as visitas aos espaços para fazer o registro fotográfico. A fim de evitar um direcionamento pessoal ao fotografar, estabelecemos previamente os locais que seriam fotografados e analisados em todos os espaços escolares pesquisados. Foram eles: a entrada da instituição, os corredores, a entrada das salas de aula, as salas de aula, o pátio/parque, o refeitório e a biblioteca.

As análises e discussões (na sequência) foram organizadas de modo a produzir o exercício analítico sobre os materiais, a partir de um conjunto de sequências fotográficas, entrecruzado com as teorizações que compõe o campo em estudo. Concomitantemente à análise das fotografias foram analisadas leis, diretrizes 
e documentos que orientam os níveis escolares da educação brasileira. A investigação desse conjunto de documentos ajudou a compreender as características arquitetônicas que eram apresentadas em cada nível educacional. Possibilitou também, perceber como o espaço arquitetônico é detalhado na legislação e como o isolamento da escola é defendido em prol da segurança escolar.

\section{Análises e discussões}

Sequência fotográfica 1 - Entrando no espaço escolar
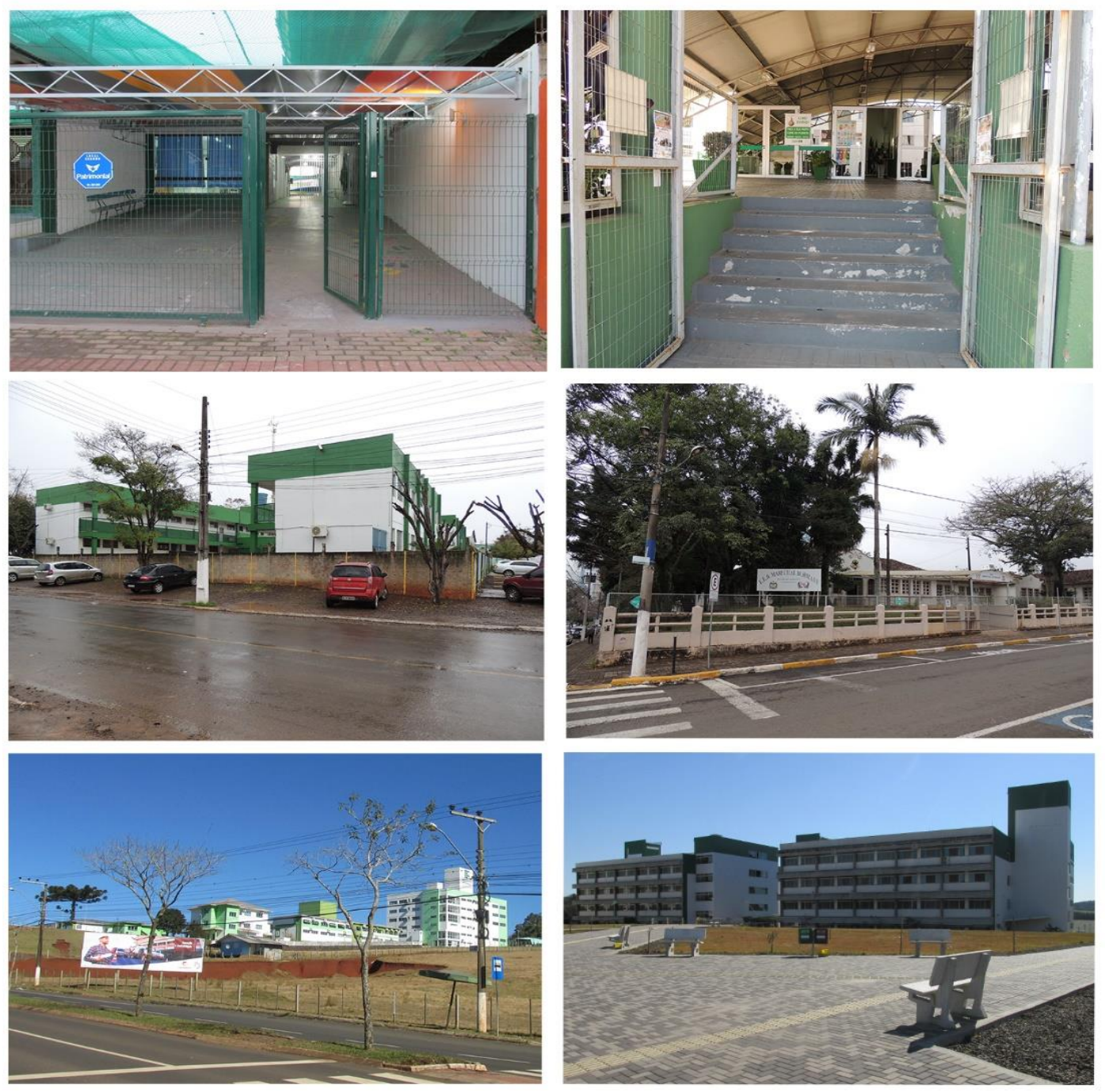

Fonte: Material de pesquisa, 2019.

Nota: Na sequência temos, respectivamente, EI1, EI2, EF1, EF2, ES1 e ES2.

Ao chegar nas instituições de Educação Básica nos deparamos com muros altos, portões de segurança e grades nas janelas. As duas únicas instituições sem muros são as de Ensino Superior, o que não significa que elas não apresentem formas de manter a segurança. A ES1 possui uma cancela e um vigia que 
pede sua identificação para entrar no campus. A ES2 tem câmeras de segurança e muitos guardas terceirizados.

A Resolução n ${ }^{\circ}$ 5, de 17 de dezembro de 2009, produzida pelo Conselho Nacional de Educação, traz as Diretrizes Curriculares Nacionais para a Educação Infantil com poucas orientações sobre o modo como o espaço destinado à primeira etapa da Educação Básica deve ser estruturado. No Art. 8, parágrafo 1, inciso VI, as orientações visam assegurar "os deslocamentos e os movimentos amplos das crianças nos espaços internos e externos às salas de referência das turmas e à instituição" (BRASIL, 2009b, p. 3). Outros dois documentos do mesmo ano trazem mais especificações sobre o que é necessário nos espaços de Educação Infantil. No documento Indicadores da Qualidade na Educação Infantil (BRASIL, 2009a), as orientações são voltadas à manutenção do espaço e a sua organização, com vistas a melhorar as experiências para as crianças. Nele é priorizada a organização dos ambientes de forma que as crianças brinquem, com possibilidade de explorar os espaços para além da creche. Incentiva, ainda, espaços que proporcionem trocas entre as crianças da mesma faixa etária e de faixas etárias diferentes; espaços limpos, bem cuidados, que possibilitem a inclusão e que estejam arrumados de modo a estimular a autonomia das crianças. Já o documento intitulado Critérios para um atendimento em creches que respeite os direitos fundamentais das crianças (CAMPOS, 2009) orienta que devem ser priorizadas, durante possíveis obras feitas nos prédios, as adequações do espaço e do mobiliário à altura das crianças, às necessidades que cada faixa etária apresenta e à qualidade dos espaços internos e externos ao número de crianças matriculadas. Indica, também, a necessidade de se manter o ambiente limpo e bem conservado. Quando afirma: "nossas crianças têm direito de correr, pular e saltar em espaços amplos, na creche ou nas suas proximidades" (CAMPOS, 2009, p. 23), chama a atenção para o espaço educador para além da instituição de Educação Infantil. Essa afirmação nos coloca a pensar sobre o modo como nossos espaços escolares se relacionam com a comunidade externa, e se oportunizam a aprendizagem fora do cercado da escola.

Olhando para tantas grades, nos perguntamos se elas são mesmo para a proteção das crianças. Faria (2012, p. 108) escreve:

[...] a escola integral precisa das ruas. Ao contrário do que muitos pensam e desejam, não quer tirar as crianças das ruas, mas, sim, dar-lhes a oportunidade e o direito do reencontro. Este reencontro não se dará tão facilmente. Entre a escola e a cidade estão erguidos altos muros. O ethos da escola urbana se caracteriza por ser um tempo-espaço desligado da cidade e de todos os estímulos socioculturais provenientes do exterior.

A autora faz com que questionemos os motivos que levam à frágil relação entre os espaços de educação formal e os espaços de educação não-formal. O uso de muros e grades se justifica pela proteção das crianças e jovens do perigo que existe do lado de fora da escola. Mas dificulta a ligação entre o espaço da escola e os demais espaços da cidade. Escolano (2001, p. 26) afirma que 
A arquitetura escolar é também por si mesma um programa, uma espécie de discurso que institui na sua materialidade um sistema de valores, como os de ordem, disciplina e vigilância, marcos para a aprendizagem sensorial e motora e toda uma semiologia que cobre diferentes símbolos estéticos, culturais e também ideológicos.

A arquitetura do espaço escolar tem relação direta com os objetivos educacionais estabelecidos pela instituição de ensino, constitui-se como elemento que possibilita um conjunto específico de práticas. $\mathrm{Na}$ busca por marcos legais que orientem a organização desses espaços, que ensinam a todas e todos que os frequentam, não encontramos outras regulamentações, para além daquelas que referem à Educação Infantil.

Sequência fotográfica 2 - Andando pelo espaço escolar
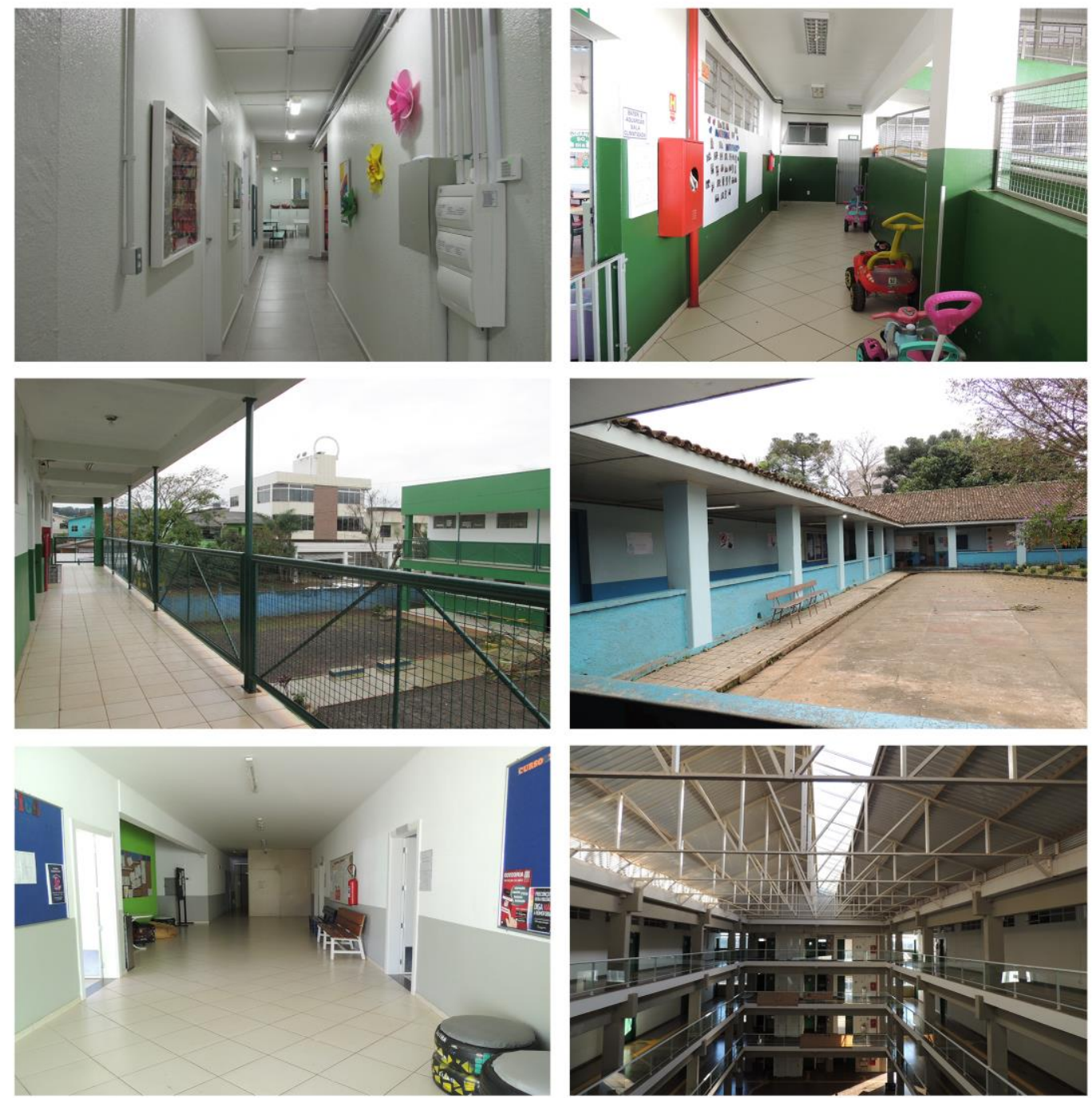

Fonte: Material de pesquisa, 2019.

Nota: Na sequência temos, respectivamente, EI1, EI2, EF1, EF2, ES1 e ES2.

Ao longo da pesquisa, andamos por muitos corredores. Alguns bem decorados e iluminados, com algumas produções das crianças, com muitos murais criados pelas professoras. Outros vazios, com pouca 
iluminação e poucas cores. Enquanto alguns corredores têm muitas informações, outros não apresentam nada, são compostos apenas por paredes brancas que levam às salas de aula. Por vezes a sensação é de espaços apertados, em outras a sensação de vigilância. Os corredores que parecem mais vigiar do que guiar até a sala de aula são os da EF1, da EF2 e os da ES2. Neles notamos elementos do modelo arquitetônico do Panóptico, de Jeremy Bentham. O modelo original era caracterizado por

[...] na periferia uma construção em anel; no centro, uma torre; esta é vazada de largas janelas que se abrem sobre a face interna do anel; a construção periférica é dividida em celas, cada uma atravessando toda a espessura da construção; elas têm duas janelas, uma para o interior, correspondendo às janelas da torre; outra, que dá para o exterior, permite que a luz atravesse a cela de lado a lado. Basta então colocar um vigia na torre central, e em cada cela trancar um louco, um doente, um condenado, um operário ou um escolar. Pelo efeito da contraluz, pode-se perceber da torre, recortando-se exatamente sobre a claridade, as pequenas silhuetas cativas nas celas da periferia. Tantas jaulas, tantos pequenos teatros, em que cada ator está sozinho, perfeitamente individualizado e constantemente visível (FOUCAULT, 1987, p. 165, grifos nossos).

Nas escolas não encontramos torres com vigias, mas a construção em anel, com os corredores vazados sem nada no centro, torna-se perfeita para que os professores, os coordenadores, os diretores e os alunos consigam visualizar quem circula, como e para onde vai. Como explica Foucault (1987, p. 166), este “dispositivo panóptico organiza unidades espaciais que permitem ver sem parar e reconhecer imediatamente". Desta maneira, a arquitetura auxilia no controle sobre os corpos, facilitando o trabalho dos professores e gestores em manter a ordem escolar, em vigiar os estudantes e punir aqueles que são pegos fora da sala em horário de aula ou comportando-se de maneira divergente da autorizada pela escola.

Segundo Foucault (1987, p. 166), o principal efeito produzido pelo panóptico é "induzir no detento um estado consciente e permanente de visibilidade que assegura o funcionamento automático do poder". Na educação, o panóptico induzirá, nas crianças e nos jovens, à ideia de que todos os adultos estão atentos aos seus comportamentos, que a qualquer deslize eles poderão e serão repreendidos e devidamente punidos. Por consequência, a arquitetura assegura o funcionamento do poder disciplinar sobre os estudantes. Künzle (2007, p. 224) explica que:

O panoptismo assume três aspectos: de vigilância, de formação e de correção. A reclusão e a vigilância numa instituição não têm como objetivo excluir, mas, ao contrário, têm a tarefa de ligar o indivíduo a um grupo, fixa-lo em um 'aparelho de transmissão de saber' para formar um determinado sujeito.

Sabemos que o objetivo da escola é formar o sujeito, mas, a partir da afirmação de Künzle (2007), cabe pensar para que estamos formando. Estamos transformando os estudantes em que tipo de sujeitos? Para que tipo de sociedade? Bánovčanová e Masaryková (2014) afirmam que o aluno funciona como um 
símbolo da disciplina, das normas e dos regulamentos da escola, que por sua vez, organiza a sala de aula de forma específica na garantia de corpos e mentes dóceis.

Sequência fotográfica 3 - As salas de aula
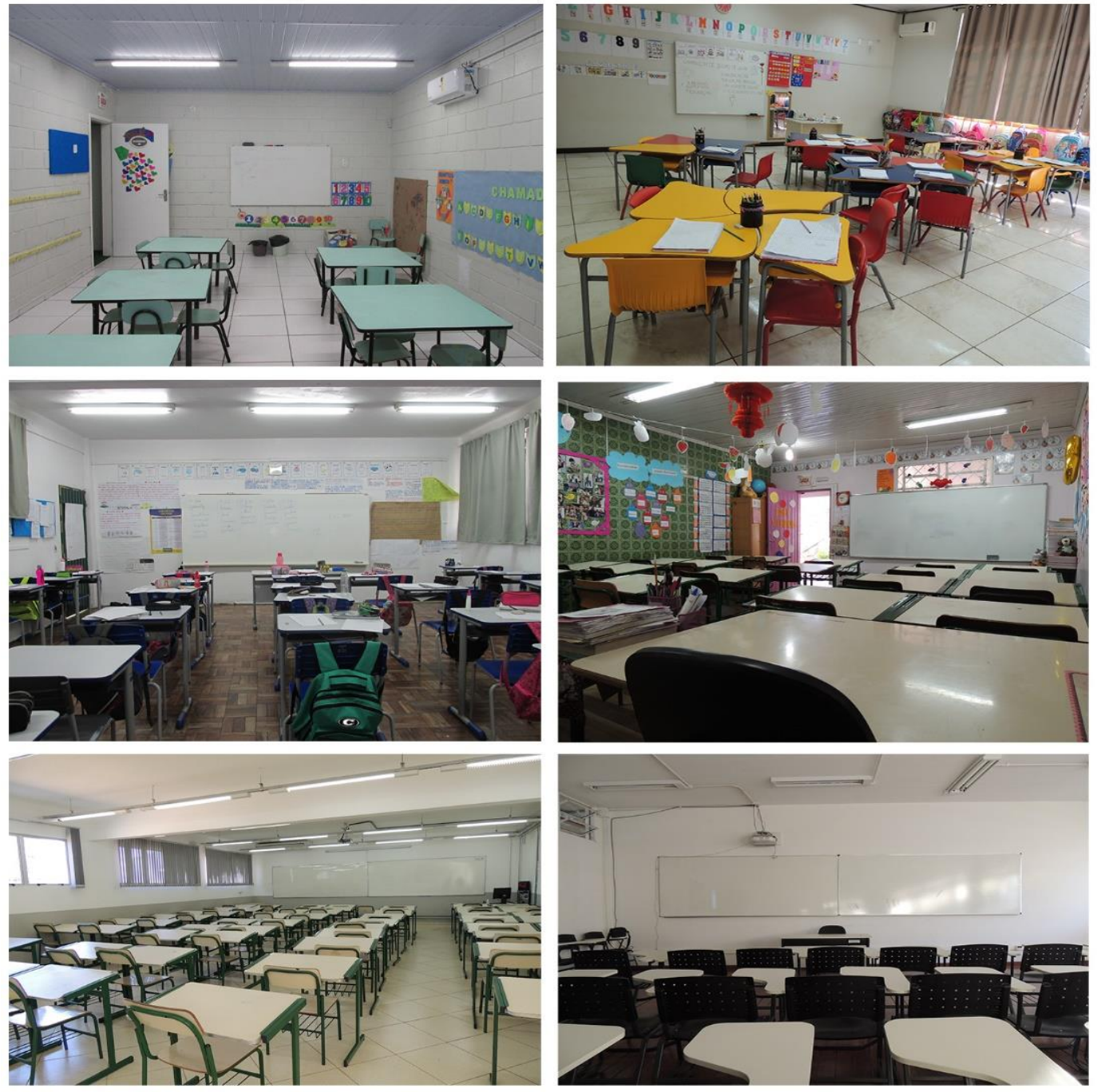

Fonte: Material de pesquisa, 2019.

Nota: Na sequência temos, respectivamente, EI1, EI2, EF1, EF2, ES1 e ES2.

Algumas salas apresentam portas de madeira ou de metal, completamente fechadas em sua estrutura. Para conseguir observar o que se passa na sala de aula é necessário abrir a porta. Outras portas são vazadas, com janelas de vidro, de maneira que qualquer pessoa que passe pela porta pode examinar o que ocorre dentro da sala de aula. Nenhuma sala possui janela na parede da porta. A maioria das salas têm janelas altas, poucas dispõe de janelas na altura das crianças. Em quase todas as salas, deparamo-nos com as carteiras em fileiras, voltadas ao quadro branco. Em cada sala que entramos o sentimento de nostalgia se mistura 


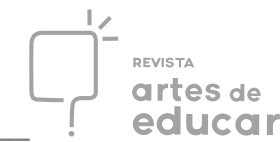

com uma indagação: por que nada mudou, por que as salas de hoje são exatamente iguais às que um dia frequentamos?

A resposta para essa indagação é clara, existe um padrão de organização do espaço da sala de aula, desenvolvido por Comenius em 1657 (na Idade Moderna, há três séculos), que continua intocável apesar das mudanças sociais, culturais e tecnológicas que passamos. O padrão criado por Comenius em Didática Magna (2011) se caracteriza por espaços organizados e controlados, transformando a escola em "uma tecnologia social" (NARODOWSKI, 2006, p. 15). Um espaço escolar pensado para proporcionar ordem, progresso, disciplina, formação moral e religiosa.

Comenius (2011) explica a ideia que gerou a organização da sala de aula que temos hoje, com o professor diante dos estudantes, de maneira que seja o centro das atenções, podendo enxergar toda a classe e ser enxergado por ela.

Não só afirmo que um único mestre pode ensinar centenas de alunos, como também reitero que assim é que deve ser, pois é de máxima utilidade tanto para quem ensina quanto para quem aprende. [...]. Além disso, se forem poucas as pessoas que ouvem um mestre, delas poderá facilmente escapar alguma coisa; ao contrário, quando são muitas, cada uma entenderá o que puder, mas com sucessivas repetições tudo voltará à mente para proveito de todos [...], também o mestre pode ensinar sem nenhum esforço, pode ensinar ao mesmo tempo, os mesmos exercícios a um grande número de alunos; assim também vemos que um único tronco basta para sustentar uma árvore muito grande e frondosa e para propiciar-lhe a linfa vital, e que o sol é suficiente para que cresçam as plantas de toda a terra. [...] Se nunca ensinar, nem em particular nem na escola, uma só pessoa, mas todas juntas e de uma só vez, em virtude do que nunca se aproximará de um aluno apenas nem permitirá que apenas um se lhe aproxime. Em vez disso, da cátedra (de onde poderá ser visto e ouvido por todos), espalhará como o sol os raios sobre todos, de tal modo que todos, com os olhos, os ouvidos e os espíritos voltados para ele, possam receber tudo o que for explicado com palavras ou mostrado com as mãos ou com os desenhos. Assim, com um único balde, não se lavam duas paredes, porém muitas (2011, p. 209).

Notamos, nesse trecho, que os princípios para o ensino defendido por Comenius (2011) são pautados por uma didática da repetição, em uma educação em massa, sendo o professor o detentor do saber, o Sol, a estrela central de todo o Sistema, quem irradia o conhecimento, quem transmite os conteúdos prontos. As salas de aula que vemos nas imagens parecem não fugir dessa didática maçante, pois "estando no lugar mais alto, o professor deve olhar em torno de si e não permitir que ninguém faça outra coisa senão olhar para ele" (COMENIUS, 2011, p. 211). Estando diante do quadro branco, diante de toda a turma, no ponto central da sala, o professor consegue vigiar cada estudante e coordenar cada atividade.

Orientando a organização do ambiente de educação da primeira infância, a Secretaria de Educação Fundamental, do Ministério da Educação criou, em 1998, o documento intitulado Subsídios para a 
elaboração de diretrizes e normas para a educação infantil, que estabelece padrões básicos de qualidade dos espaços de cuidar e educar crianças. $\mathrm{O}$ documento explica que

As instituições de educação infantil, assim como toda instituição educacional, convivem com o binômio "atenção/controle": ao mesmo tempo em que é dada a necessária atenção às crianças, elas também estão sendo controladas para aprenderem a viver em sociedade. Cabe garantir que a balança penda para a "atenção", e que o "controle" esteja voltado não para o individualismo, o conformismo e a submissão, mas para o verdadeiro aprendizado de vida em sociedade: solidariedade, generosidade, cooperação, amizade (BRASIL, 1998, p. 96, grifos nossos).

Nesse sentido, cabe pensar sobre o modo como a arquitetura engessada das escolas e a organização tradicional do espaço da sala de aula afetam a proposta pedagógica das professoras e professores. Pois, a partir do momento em que a/o docente não tem, ao seu dispor, espaços e mobiliários flexíveis para (re)elaborar as dinâmicas das aulas, acaba presa/o ao tradicionalismo, contribuindo para a submissão da criança ao professor. Porém, assim como o espaço da sala de aula afeta a proposta docente, as professoras e professores também podem afetar/modificar os espaços da escola. Essa mudança dependerá da concepção de educação das/dos professoras/professores e de sua disposição para fazer mudanças. Esse potencial para modificar o que está posto na escola tem relação direta com o poder que "funciona e se exerce em rede" (FOUCAULT, 2014, p. 284), pelos indivíduos presentes nesses espaços escolares. Na obra Microfísica do poder, Foucault (2014, p. 238) afirma que

[...] se o poder só tivesse a função de reprimir, se agisse apenas por meio da censura, da exclusão,
do impedimento, do recalcamento, à maneira de um grande superego, se apenas se exercesse de um
modo negativo, ele seria muito frágil. Se ele é forte, é porque produz efeitos positivos no nível do
desejo - como se começa a conhecer - e também a nível do saber. O poder, longe de impedir o
saber, o produz. Se foi possível constituir um saber sobre o corpo, foi através de um conjunto de
disciplinas militares e escolares. Foi a partir de um poder sobre o corpo que foi possível um saber
fisiológico, orgânico.
O enraizamento do poder, as dificuldades que se enfrenta para se desprender dele vêm de todos
estes vínculos (grifos nossos).

É preciso perceber o poder para além de sua versão perversa de repressão. Cada indivíduo presente no espaço escolar é submetido ao poder, mas também o exerce. Consequentemente, nenhum sujeito é apenas submisso, todo sujeito é dotado de poder e capaz de resistir a ele. As professoras e professores, a equipe gestora e demais indivíduos pertencentes à comunidade escolar, podem desempenhar poder com efeito positivo, repensar a educação e seus espaços, produzir saber sobre a organização dos espaços escolares e sobre as propostas docentes. A força positiva desse poder refletiria nas propostas pedagógicas capazes de superar as limitações físicas dos espaços. 
Sequência fotográfica 4 - Os refeitórios
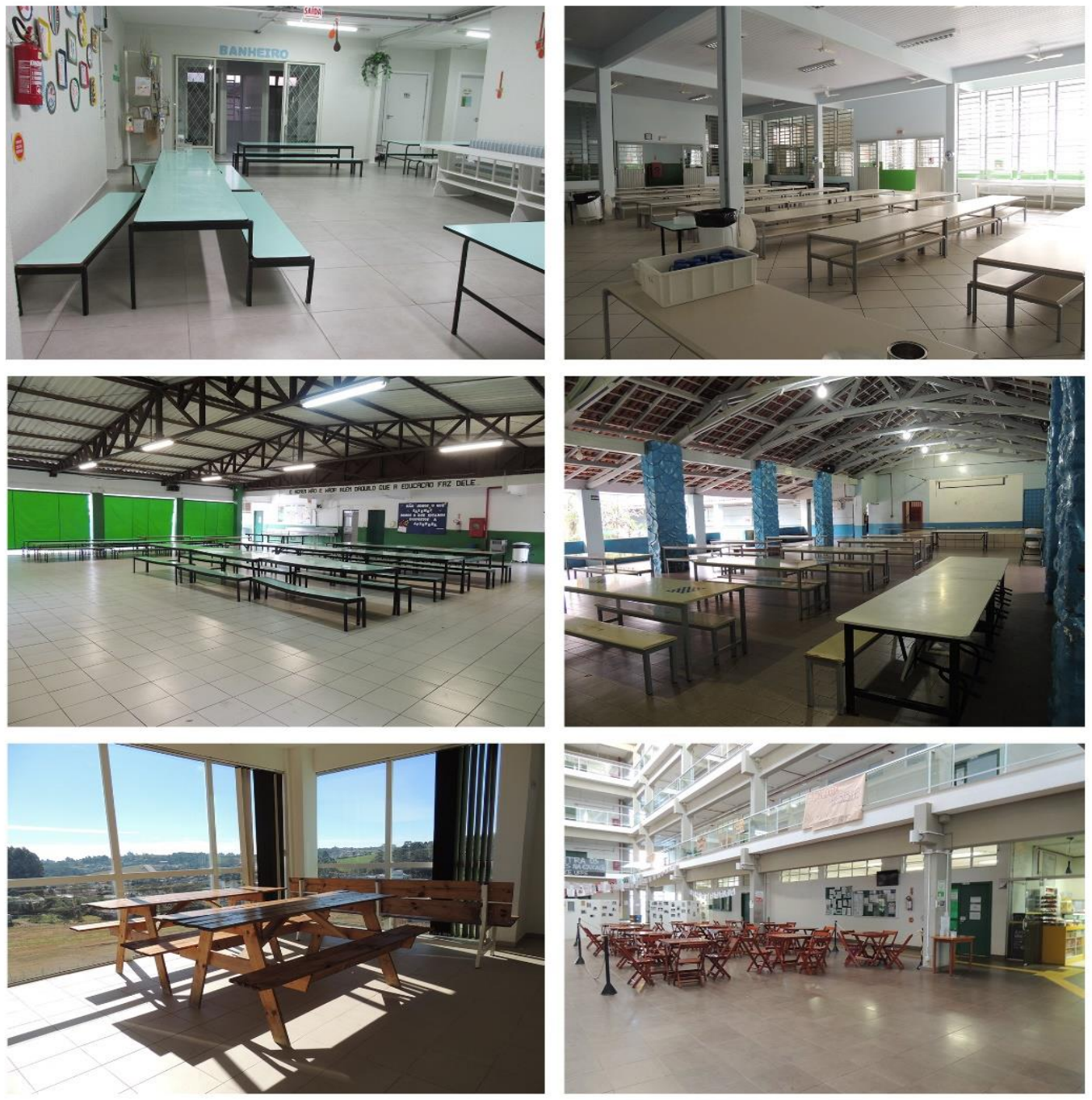

Fonte: Material de pesquisa, 2019.

Nota: Na sequência temos, respectivamente, EI1, EI2, EF1, EF2, ES1 e ES2.

Comenius, autor da obra Didática Magna (2011), foi o responsável pela mudança da concepção de educação e orientação das propostas educacionais da Idade Moderna. No capítulo XXXII, de nome $A$ organização universal e perfeita das escolas no livro Didática Magna, encontramos os conselhos de Comenius sobre como a escola deveria se organizar. Comparando a educação à arte tipográfica, o autor chama a sua proposta pedagógica de didacografia, explicando que

O papel são os alunos, cuja mente é impressa com os caracteres da ciência. Os caracteres tipográficos são os livros escolares e todos os outros instrumentos didáticos, por meio dos quais as matérias que devem ser aprendidas são impressas com facilidade nas mentes. A tinta é voz do mestre, quando, a partir dos livros, ele transmite o sentido das coisas para as mentes dos alunos. A prensa é a disciplina escolar, que predispõe e obriga todos a observar os ensinamentos (COMENIUS, 2011, p. 364). 
Mais à frente, na mesma obra, Comenius reforça o papel da disciplina como forma de manter a obediência, e constrói uma prática pedagógica pautada na vigilância e no controle por meio da violência justificada. Para ele,

[...] ninguém que frequente a escola para receber instrução poderá escapar da disciplina comum. Os graus dessa disciplina são: 1) atenção constante; e como não é seguro confiar na diligência e na inocência dos alunos (pois são progênie de Adão), todos deverão ser acompanhados pelo olhar, para onde quer que se voltem; 2) repreensão, para trazer logo de volta ao caminho da razão e da obediência quem dele sair; 3) castigo, para quem se recusar deixar-se guiar por conselhos e advertências. Mas tudo deve ser feito com prudência e sem outro fim que não seja o de tornar todos entusiasmados e industriosos em seus afazeres (2011, p. 366-367).

A partir da proposta didática criada pelo autor, o sistema educacional vai ganhando sentido pela transmissão de ideias prontas aos estudantes, pelo disciplinamento tanto dos estudantes como dos professores, por meio de regras de conduta, e pela manutenção de uma ordem social já estabelecida. Consequentemente, nesta perspectiva teórica, cria-se uma pedagogia do vigiar, que disciplina os corpos, tornando-os dóceis, por meio de estratégias de dominação, como a arquitetura. Uma arquitetura fechada como a das prisões -, cercada de muros e de cercas elétricas. Um espaço escolar que determina como os sujeitos devem ocupar a sala de aula. Um espaço com organização própria, uma organização voltada ao comportamento esperado de seus alunos.

Como orientou Comenius (2011, p. 127), “a arte de ensinar não exige mais que uma disposição tecnicamente bem feita do tempo, das coisas e do método". A escola, como instrumento de manutenção do domínio sobre o corpo, deveria manter uma ordem exata sobre tudo e todos. Comenius (2011, p. 123) justifica a ordem escolar ao declarar "o que está ordenado, enquanto mantiver a ordem, conservar-se-á intacto e no mesmo estado; se, ao contrário, a ordem vier a faltar, então começará a languescer, vacilar, ceder e a arruinar-se". Portanto, os espaços organizados de forma separada mantêm não apenas o funcionamento dessa ordem escolar, mas também facilitam a vigilância e, consequentemente, o domínio sobre os corpos dos estudantes.

A maioria dos refeitórios com os quais nos deparamos, com exceção do refeitório da ES1, estão localizados no centro da instituição, em pontos de fácil visibilidade, organizados da maneira que serão utilizados pelos estudantes. Tudo disposto de forma técnica, muito bem preparado para o tempo de recreio/intervalo de cada turma. Na ES1 encontramos mais de um refeitório, o que chama a atenção é o espaço retratado na quinta fotografia acima, com uma vista ampla para o campus e iluminação natural, constituindo um ambiente agradável e mais reservado para os estudantes. 
Essa ordem escolar, desenvolvida por Comenius (2011), onde para tudo se tem um momento, onde cada atividade deve ser desenvolvida em um determinado horário, não é uma característica apenas da escola. Na obra Vigiar e punir: nascimento da prisão, Foucault (1987) expõem o regulamento da Casa dos jovens detentos de Paris. Segundo ele, o dia dos detentos começava cedo, com um rufar de tambor todos acordavam, vestiam seus uniformes, tudo em silêncio. Em seguida, outro sinal marcava a hora de arrumar a cama, e outro sinal para formar uma fila para a ida à capela, onde eram feitas orações. Depois, no pátio, faziam a higienização de suas mãos, recebiam o café da manhã e seguiam para o local de trabalho. Paravam o trabalho para almoçar, possuíam um pequeno momento de recreio e duas horas de ensino na escola. Ao final das atividades de ensino, os detentos voltavam para as atividades de trabalho, permanecendo lá até o horário do jantar. Quando o jantar terminava, os detentos tinham outro recreio, logo em seguida voltavam ao trabalho. No total eram nove horas de trabalho, e ao fim dessas nove horas eram realizadas uma leitura e uma oração. Depois da inspeção, os detentos seguiam para suas celas, com um primeiro sinal para trocar de roupas e o segundo para deitar na cama. Por fim, "fecham-se as portas das celas e os vigias fazem a ronda nos corredores para verificarem a ordem e o silêncio" (FOUCAULT, 1987, p. 11).

$\mathrm{Na}$ escola o cronômetro funciona da mesma maneira, para tudo há uma ordem, um horário e um local. Sobre essa distribuição dos tempos, abrimos um parêntesis para destacar que o regulamento do colégio que uma de nós frequentou, por exemplo, na terceira série do Ensino Fundamental I, no ano de 2004, determinava o seguinte: o portão da escola abria às sete horas e quinze minutos, em ponto. Os estudantes que chegavam eram orientados a ficar no pátio, esperando o toque do sinal. Às sete horas e trinta minutos o sinal tocava e todos os estudantes deveriam formar uma fila de sua respectiva turma. Os professores orientavam a composição da fila, que era feita em direção à bandeira hasteada do Brasil. Todos cantavam o hino nacional, exceto aqueles que não estavam adequadamente vestidos com o uniforme escolar. As crianças que chegavam atrasadas eram orientadas a esperar o final da atividade do hino nacional para entrar na escola. Às sete horas e quarenta minutos todos seguiam para as suas salas de aula, onde deveriam sentar nas carteiras já organizadas em fileiras, todos deveriam obedecer a ordem e manter silêncio. As aulas seguiam em sequência, se as duas primeiras aulas eram de Português, uma outra seria de Ciências, outra de Matemática e outra de Educação Física. O tempo de cada uma era orientado pelo som do sinal, que marcava o início e o fim de cada tempo de aula. Cada turma possuía um horário específico ao seu recreio, desta forma não haveria tumulto entre as turmas. Às nove horas e quarenta minutos a turma da terceira série era liberada para vinte minutos de recreio. A turma era orientada até o refeitório do colégio, cada um podia pegar seu lanche e fazer sua refeição. No recreio, as crianças podiam ir até o pátio, onde brincavam, sempre com a supervisão de um inspetor. Às dez horas, com o tocar do sinal, a turma deveria ir para a sala, continuar os estudos, lembrando sempre de manter a sala em ordem e estar em silêncio. Seguia 
assim até o horário mais esperado, até o sinal mais aguardado, o sinal que indicava o fim do turno escolar. O horário de saída da escola era às onze horas e quarenta minutos, se os responsáveis pelos alunos não chegassem dentro de vinte minutos, as crianças eram levadas para a sala da coordenação, local onde os aguardavam.

Hoje, nossas escolas ainda se organizam a partir de horários programados para cada atividade, para cada disciplina escolar, para cada refeição. Porém, ao contrário dos detentos da prisão descrita por Foucault (1987), nossas crianças, são liberadas, têm a sensação de que o aprisionamento na escola acaba ao soar do último sinal do turno, e que só retornarão no dia seguinte. Um detento não dispõe de sua liberdade, não pode escolher o que fará depois de almoçar e terminar as lições/temas/deveres de casa. Nossos pequenos estudantes são controlados pela educação escolar durante quatro horas por dia, um prisioneiro é controlado em todas as vinte e quatro horas do dia. Mesmo nesses dois casos tão distintos (escola e prisão), encontramos semelhanças na organização, manutenção e educação do corpo. Corpo que é regulado por anos, disciplinado a partir do tempo, do espaço e dos limites que lhe são impostos. Controle que recai não apenas sobre o corpo, mas também sobre os pensamentos, os conceitos morais e a própria existência. 
Sequência fotográfica $5-\mathrm{O}$ lugar de lazer e convivência - parques e pátios
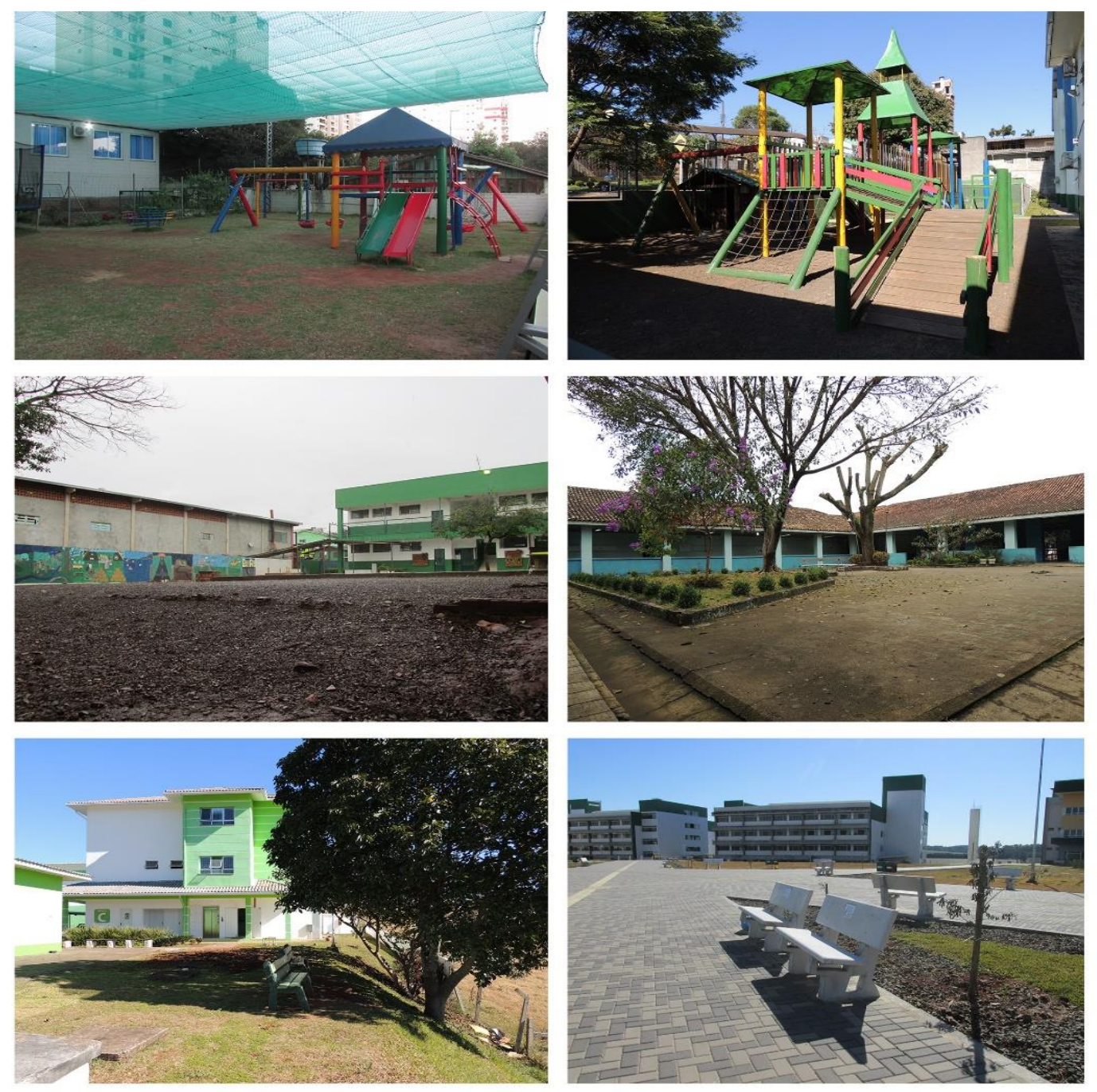

Fonte: Material de pesquisa, 2019.

Nota: Na sequência temos, respectivamente, EI1, EI2, EF1, EF2, ES1 e ES2.

A escola não é uma prisão, mas até a prisão tem um lugar de convivência, um lugar onde os detentos podem tomar sol e respirar ar fresco. Nos espaços escolares também há ambientes assim, pátios abertos, parques coloridos, ambientes de convivência, descanso e brincadeira. Todas as instituições pesquisadas apresentam espaços abertos. A EI1 dispõe de um parque pequeno, porém bem arejado, com grama natural. Na EI2 não há grama, apenas cascalhos, mesmo no espaço com escorregador e castelinho. Na EF1, também não existe área com grama, tanto o pátio, como o parque são de cascalho. A EF2 possui um pátio centralizado no meio da escola, funcionado como um panóptico, já na parte destinada às crianças, no fundo da instituição, há um parque grande, porém sem grama, apenas cascalho. As duas instituições públicas de educação superior (ES1 e ES2) apresentam uma grande área externa com grama e bancos para seus estudantes. 
Ao analisar o documento Diretrizes Curriculares Nacionais Gerais para a Educação Básica, criado a partir da Resolução $n^{\circ}$, de 13 de julho de 2010, buscamos compreender suas orientações para as estruturas arquitetônicas dos espaços de educação formal. Durante a pesquisa, deparamo-nos com a falta de esclarecimento e aprofundamento sobre tais orientações no documento. Com o objetivo de "transformar a Educação Básica em um sistema orgânico, sequencial e articulado" (BRASIL, 2010, p. 824), o documento propõe o respeito a autonomia e a identidade das instituições educacionais. As diretrizes pressupõem "VI compatibilidade entre a proposta curricular e a infraestrutura entendida como espaço formativo dotado de efetiva disponibilidade de tempos para a sua utilização e acessibilidade” (BRASIL, 2010, p. 825, grifo nosso). Neste item, percebe-se que o espaço escolar e o tempo não se dissociam e que são compreendidos como educativos. No documento fica subentendido que a finalidade da organização é a formação. Mas, qual formação? Se for uma formação dedicada apenas ao corpo e sua docilidade, a submissão às regras, aos horários e aos espaços pré-determinados, então novamente o espaço e o tempo dedicam-se a dominar quem nele está.

Mais à frente, o documento amplia sua concepção de espaço formativo:

I - concepção e organização do espaço curricular e físico que se imbriquem e alarguem, incluindo espaços, ambientes e equipamentos que não apenas as salas de aula da escola, mas, igualmente, os espaços de outras escolas e os socioculturais e esportivo-recreativos do entorno, da cidade e mesmo da região [...];

$\mathrm{V}$ - organização da matriz curricular entendida como alternativa operacional que embase a gestão do currículo escolar e represente subsídio para a gestão da escola (na organização do tempo e do espaço curricular, distribuição e controle do tempo dos trabalhos docentes), passo para uma gestão centrada na abordagem interdisciplinar, organizada por eixos temáticos, mediante interlocução entre os diferentes campos do conhecimento;

VI - entendimento de que eixos temáticos são uma forma de organizar o trabalho pedagógico, limitando a dispersão do conhecimento, fornecendo o cenário no qual se constroem objetos de estudo, propiciando a concretização da proposta pedagógica centrada na visão interdisciplinar, superando o isolamento das pessoas e a compartimentalização de conteúdos rígidos (BRASIL, 2010, p. 825, grifos nossos).

A partir desta proposta de organização do trabalho pedagógico, entendemos que as escolas, seus espaços e seus currículos não podem ser engessados, mas sim, flexíveis, capazes de se relacionar com outras instituições, com a cidade, com a população, mas sem perder a organização sequencial estabelecida há séculos por Comenius (2011). Sobre essa organização, justifica-se que "cada etapa é delimitada por sua finalidade" (BRASIL, 2010, p. 826). A respeito da arquitetura das instituições não encontramos nenhuma orientação específica, apenas algumas observações no Capítulo II: Modalidades da educação básica. Nele a Seção II: Educação Especial (BRASIL, 2010, p. 826) garante "a acessibilidade arquitetônica, nas comunicações e informações, nos mobiliários e equipamentos e nos transportes"; e a Seção V: Educação 
Escolar Indígena (BRASIL, 2010, p. 827) assegura a "edificação de escolas que atendam aos interesses das comunidades indígenas". O Capítulo II: Avaliação, do Título VII: Elementos constitutivos para a organização das Diretrizes Curriculares Nacionais Gerais para a Educação Básica, divide-se em três dimensões básicas, no Art. 46 (BRASIL, 2010, p. 827): “I - avaliação da aprendizagem; II - avaliação institucional interna e externa; III - avaliação de redes de Educação Básica”. Mas, em suas seções de Avaliação institucional (Seção III) e Avaliação de redes de Educação Básica (Seção IV) nada encontramos sobre a avaliação do espaço escolar, de sua arquitetura. Mesmo com o Art. 53 afirmando que "os resultados dessa avaliação sinalizam para a sociedade se a escola apresenta qualidade suficiente para continuar funcionando como está" (BRASIL, 2010, p. 827), nada é dito sobre como a qualidade do espaço é capaz de afetar tanto os resultados educacionais, como o funcionamento adequado da instituição.

Por que nossas Leis não preveem a avaliação da arquitetura escolar? Se, em seu Art. 55, as Diretrizes Curriculares Nacionais Gerais para a Educação Básica (BRASIL, 2010, p. 827) buscam

Criar e recriar o trabalho da e na escola mediante [...]; V - a instauração de relações entre os estudantes, proporcionando-lhes espaços de convivência e situações de aprendizagem, por meio dos quais aprendam a se compreender e se organizar em equipes de estudos e de práticas esportivas, artísticas e políticas.

Por que os documentos oficiais deixam de fora a avaliação do espaço formativo, do espaço educativo, de convívio, de ensino e de aprendizagem? Ribeiro (2004, p. 105), diz que “o espaço aparentemente estático é fruto de um processo dinâmico de uma rede de relações, da forma como o Estado atua através das políticas públicas”. Entendido desta forma, o espaço escolar não é neutro, ele é carregado de posicionamentos, de poderes e contra-poderes. A não avaliação deste espaço é uma tomada de decisão comprometida com o status quo, é decidir que o espaço escolar não precisa ser avaliado, (re)pensado e modificado, mesmo que novas demandas apareçam. 
Sequência fotográfica 6 - As bibliotecas
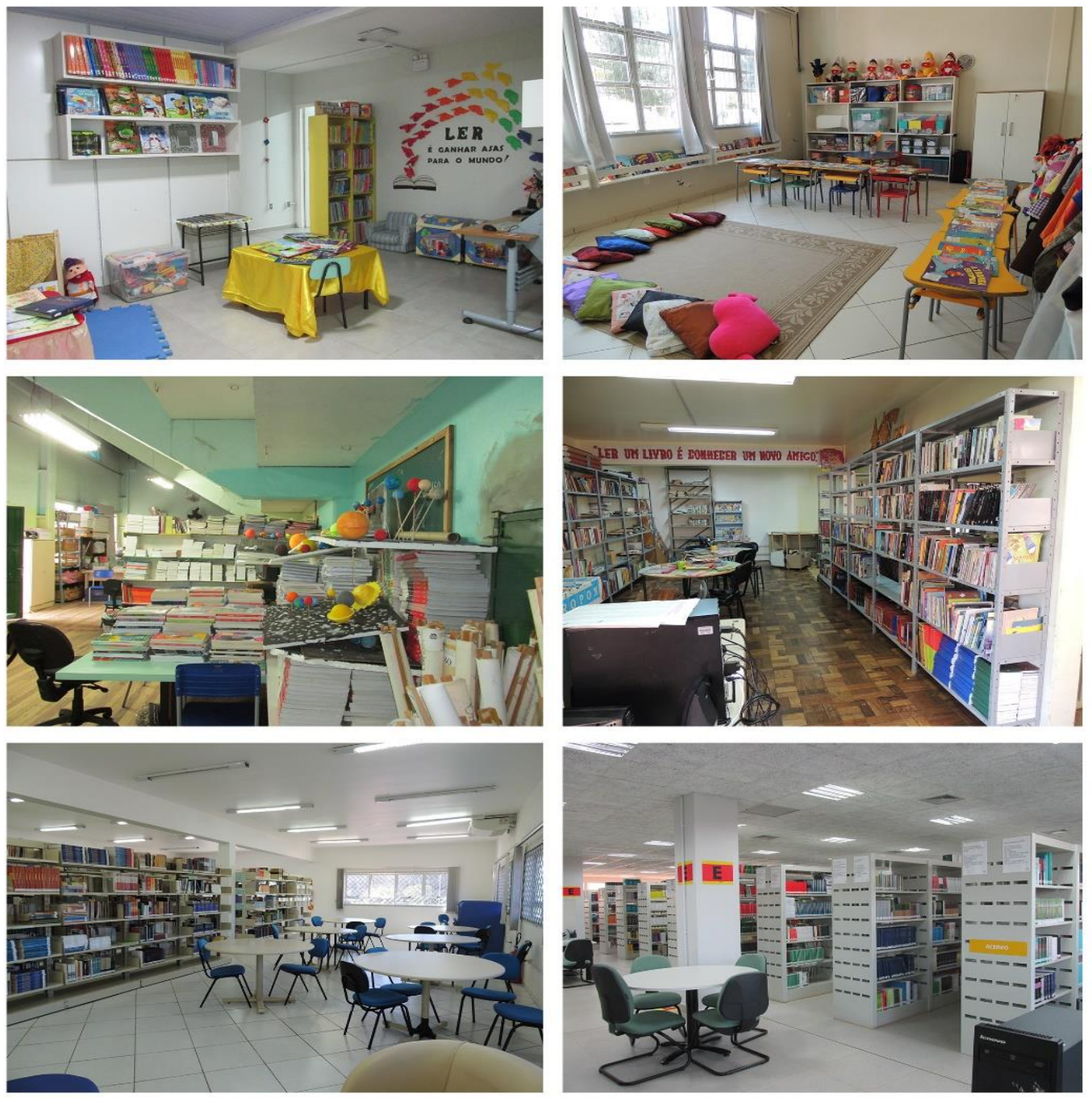

Fonte: Material de pesquisa, 2019.

Nota: Na sequência temos, respectivamente, CEIM 1, CEIM 2, EB 1, EB 2, IES 1 e IES 2.

A biblioteca, repleta de possibilidades, poesias, contos, romances, estórias e História, é um lugar que, se não for bem organizado e utilizado, pode se transformar em um armazém, um depósito de livros, um local morto. Nas escolas pesquisadas observamos as diferentes formas de organização das bibliotecas escolares. Na primeira foto acima, no EI1, a biblioteca é pequena e fica localizada no meio dos corredores, torna-se local de passagem de quase todas as turmas, o que dá a sensação de que é um lugar aberto, receptivo, destinado a todos da escola.

No EI2, uma sala de aula foi destinada à Biblioteca e outra à Brinquedoteca. A biblioteca é cheia de livros, fantasias e fantoches, com espaço para que as crianças leiam e imaginem. A biblioteca da EB1 está improvisada em uma sala afastada, uma sala úmida, com muitos livros, apostilas e materiais didáticos amontoados. Esse espaço está configurado deste jeito porque o projeto criado pela gestão para a construção de sua biblioteca ainda está em elaboração.

Revista Interinstitucional Artes de Educar. Rio de Janeiro, V. 6 N. 3 - pag 1113-1138 (set - dez 2020): "Itinerâncias entre Michel Foucault e 
A biblioteca da EB2 possui um grande acervo, com pequenos espaços para a leitura de livros e alguns para uso dos computadores. As bibliotecas da ES1 e da ES2 se assemelham, ambas são claras, bem iluminadas, com mesas e computadores disponíveis para os estudantes. A biblioteca da ES2 conta com um diferencial, mesmo com algumas salas destinadas para setores específicos da administração acadêmica em seu projeto, o prédio foi criado para destinar-se especialmente à biblioteca, com salas de estudo, guardavolumes etc.

Na Constituição Federal de 1988, nada é dito sobre a arquitetura escolar, não é lançada nenhuma norma arquitetônica para os espaços escolares. Na Lei de Diretrizes e Bases da educação nacional, que “disciplina a educação escolar” (BRASIL, 1996, p. 1), no que refere ao espaço escolar, existem orientações de âmbito geral, sobre condições de acesso e de permanência na escola. O Art. 9 assegura que a União estará encarregada de "IX - autorizar, reconhecer, credenciar, supervisionar e avaliar, respectivamente, os cursos das instituições de educação superior e os estabelecimentos do seu sistema de ensino" (BRASIL, 1996, p. 4). No Art. 10, a mesma incumbência é dada aos Estados, para com seus sistemas de ensino. Assegura-se, também, que os estabelecimentos de ensino deverão garantir um ambiente escolar seguro e com condições materiais.

Desenvolvido pelo Instituto Nacional de Estudos e Pesquisas Educacionais Anísio Teixeira (INEP), o Sistema Nacional de Avaliação da Educação Superior (SINAES) foi criado pela Lei $\mathrm{n}^{\circ} 10.861$, de 14 de abril de 2004, e "tem como finalidade a melhoria da qualidade da educação nos cursos de graduação e instituições de educação superior [IES]" (INEP, 2017a, p. 5). O diagnóstico feito por esse sistema tem como uma de suas etapas a avaliação in loco, isto é, uma avaliação feita presencialmente, por vista às instituições, pela comissão de avaliadores. Nela os avaliadores preenchem um relatório desenvolvido pelo IES, desenvolvendo o chamado "Conceito Institucional - CI, guardado em cinco níveis" (INEP, 2017a, p. 5).

Para a avaliação in loco, foi criado o Instrumento de avaliação institucional externa: Presencial e a distância-Credenciamento, o documento "é a ferramenta dos avaliadores na verificação dos cinco eixos [Planejamento e Avaliação Institucional; Desenvolvimento Institucional; Políticas Acadêmicas; Políticas de Gestão; Infraestrutura], que contemplam as dez dimensões do Sinaes” (INEP, 2017a, p. 6). Segundo o documento,

O cálculo utilizado para obter o CI considera pesos atribuídos aos cinco eixos do Instrumento de Avaliação. Assim, para o ato de credenciamento, o eixo 1 (Planejamento e Avaliação Institucional) possui peso 10, enquanto o eixo 2 (Desenvolvimento institucional) tem peso 30; cada um dos três eixos restantes (3Políticas acadêmicas, 4-Políticas de gestão e 5-Infraestrutura) possui peso 20 (INEP, 2017a, p. 6). 
O Eixo 5, destinado a avaliação da infraestrutura, é dividido por dezoito indicadores, são eles: Instalações administrativas (Indicador 5.1); Salas de aula (Indicador 5.2); Auditório(s) (Indicador 5.3); Salas de professores (Indicador 5.4); Espaços para atendimento aos discentes (Indicador 5.5); Espaços de convivência e de alimentação (Indicador 5.6); Laboratórios, ambientes e cenários para práticas didáticas: infraestrutura física (Indicador 5.7); Infraestrutura física e tecnológica destinada à CPA (Indicador 5.8); Bibliotecas: infraestrutura (Indicador 5.9); Bibliotecas: plano de atualização do acervo (Indicador 5.10); Salas de apoio de informática ou estrutura equivalente (Indicador 5.11); Instalações sanitárias (Indicador 5.12); Estrutura dos polos EaD (Indicador 5.13); Infraestrutura tecnológica (Indicador 5.14); Infraestrutura de execução e suporte (Indicador 5.15); Plano de expansão e atualização de equipamentos (Indicador 5.16); Recursos de tecnologias de informação e comunicação (Indicador 5.17); Ambiente Virtual de Aprendizagem - AVA (Indicador 5.18).

Os indicadores 5.1, 5.2, 5.4, 5.5, 5.6, 5.7 e 5.12, nos critérios de análise das instituições, destacam como ponto importante para o diagnóstico, se a instituição considera/possui ou não um plano de avaliação periódica dos espaços. Esse critério aparece a partir do Conceito Institucional (CI) de nível 3. Sendo assim, percebemos que o espaço físico e a necessidade de sua avaliação são valorizados, já que, de acordo com o documento, os "valores iguais ou superiores a três [obtidos no Conceito Institucional] indicam qualidade satisfatória" (INEP, 2017a, p. 5). Isto é, as instituições que não apresentam a avaliação periódica dos espaços físicos, que não avaliam suas condições físicas, não se encaixam nos conceitos de nível 3, 4 e 5, que indicam a qualidade institucional.

A Educação Básica também possui seu próprio sistema de avaliação, chamado de Sistema de Avaliação da Educação Básica (SAEB), desenvolvido pelo Inep. Segundo sua cartilha, o SAEB

Tem como objetivo avaliar a qualidade, a equidade e a eficiência da educação básica brasileira. Além disso, gera dados e indicadores que subsidiam a elaboração e o monitoramento das políticas educacionais do País. Os resultados também são usados para calcular o Índice de desenvolvimento da Educação básica (ideb), que considera o desempenho dos alunos no Saeb e os dados de fluxo escolar do Censo Escolar, fornecendo indícios sobre a qualidade do ensino ofertado (INEP, 2019a, p. $3)$.

Estes indicadores são obtidos com a aplicação de questionários eletrônicos e provas para turmas de Educação Infantil, Ensino Fundamental (I e II), e questionários eletrônicos destinados a equipe gestora da amostra de escolas (Gestores, Coordenadores, Professores e Auxiliares de Sala da Educação Infantil), bem como Secretários Estaduais e Municipais de Educação. Os dados são avaliados e compreendidos como “evidências para formulação e reformulação de políticas públicas educacionais” (INEP, 2019a, p. 3). Na 
página eletrônica do Inep, na parte destinada aos Instrumentos de avaliação, encontramos a seguinte informação:

As avaliações do Saeb (Aneb/Anresc) são acompanhadas de questionários contextuais. Eles são aplicados aos alunos, professores e diretores. Também há um questionário que deve ser preenchido pelos aplicadores, com informações sobre a escola [...]. Os questionários da escola, preenchidos pelos aplicadores, abordam questões sobre as condições de infraestrutura, segurança e recursos pedagógicos disponíveis (INEP, 2019b, s/p, grifo nosso).

O questionário mais recente, disponível na página eletrônica, refere ao ano de 2017. Destinado exclusivamente aos aplicadores da avaliação, é dividido em sete categorias de avaliação: 1) avaliação do estado de conservação dos itens e equipamentos do prédio; 2) avaliação da quantidade de salas de aula existentes; 3) avaliação de aspectos relacionados à segurança da escola e dos alunos; 4) indicação da existência ou não dos recursos e suas condições de uso; 5) indicação da existência e das condições de uso dos espaços da escola; 6) avaliação da biblioteca e/ou sala de leitura; 7) indicação da existência ou não da possibilidade dos usuários da biblioteca e/ou sala de leitura levarem livros para casa.

As categorias 1, 4 e 5, e parte da categoria 3, são avaliadas em forma de questões de assinalar, com quatro respostas possíveis: a) bom, considerado em bom estado de conservação; b) regular, necessita de pequena reforma; c) ruim, necessita de grande reforma; d) inexistente. As demais categorias também possuem opções para assinalar, como "sim", "não", "sim, poucos", “sim, muitos", "todas”, "mais da metade", "menos da metade", "nenhuma", "não há" e "não porque". O questionário possui apenas duas páginas e está organizado de uma forma bastante técnica. Suas perguntas se destinam a todos os espaços da instituição escolar, seus equipamentos e instalações. Uma categoria que chama a atenção é a avaliação dos aspectos em relação à segurança da escola e dos alunos, nela encontramos 15 questões de múltipla escolha, com as opções citadas acima. As perguntas destinam-se ao:

22. Controle de entrada e saída de alunos. 23. Controle de entrada de pessoas estranhas na escola. 24. Vigilância para o período diurno. 25. Vigilância para o período noturno. 26. Vigilância para os finais de semana e feriados. 27. Esquema de policiamento para inibição de furtos, roubos e outras formas de violência. 28. Esquema de policiamento para inibição de tráfico de tóxicos/drogas dentro da escola. 29. Esquema de policiamento para inibição de tráfico de tóxicos/drogas nas imediações da escola. 30. Sistema de proteção contra incêndio (alarme de fumaça e temperatura, extintores contra incêndio dentro do prazo de validade, mangueiras etc.). 31. Iluminação do lado de fora da escola. 32. Há muros, grades ou cercas em condições de garantir a segurança dos alunos? (Caso existam buracos ou aberturas que permitam o acesso de estranhos, responder NÃO.) 33. Os equipamentos mais caros (computadores, projetores, televisão, vídeo etc.) são guardados em salas seguras ou possuem mecanismos de proteção (cadeados, grades, travas, trancas etc.)? 34. Os portões que dão acesso à parte externa permanecem trancados durante 
o horário de funcionamento da escola? 35. A escola adota alguma medida de segurança para proteger os alunos nas suas imediações? 36. A escola apresenta sinais de depredação (vidros, portas e janelas quebradas, lâmpadas estouradas etc.)? (INEP, 2017b, s/p).

Desta forma, os critérios que avaliam a segurança que a escola proporciona aos seus estudantes também avaliam o controle que a escola tem sobre os indivíduos. Pois, à medida que controla a entrada e a saída de pessoas, vigia o espaço em todos os turnos do dia, se preocupa em manter os muros, as grades e as cercas em condições perfeitas, sem que ninguém possa entrar ou sair por elas, e mantém seus portões devidamente trancados no horário de funcionamento da escola, monitoram e fiscalizam as ações de todos, disciplinam.

Sequência fotográfica 7 - Os bancos
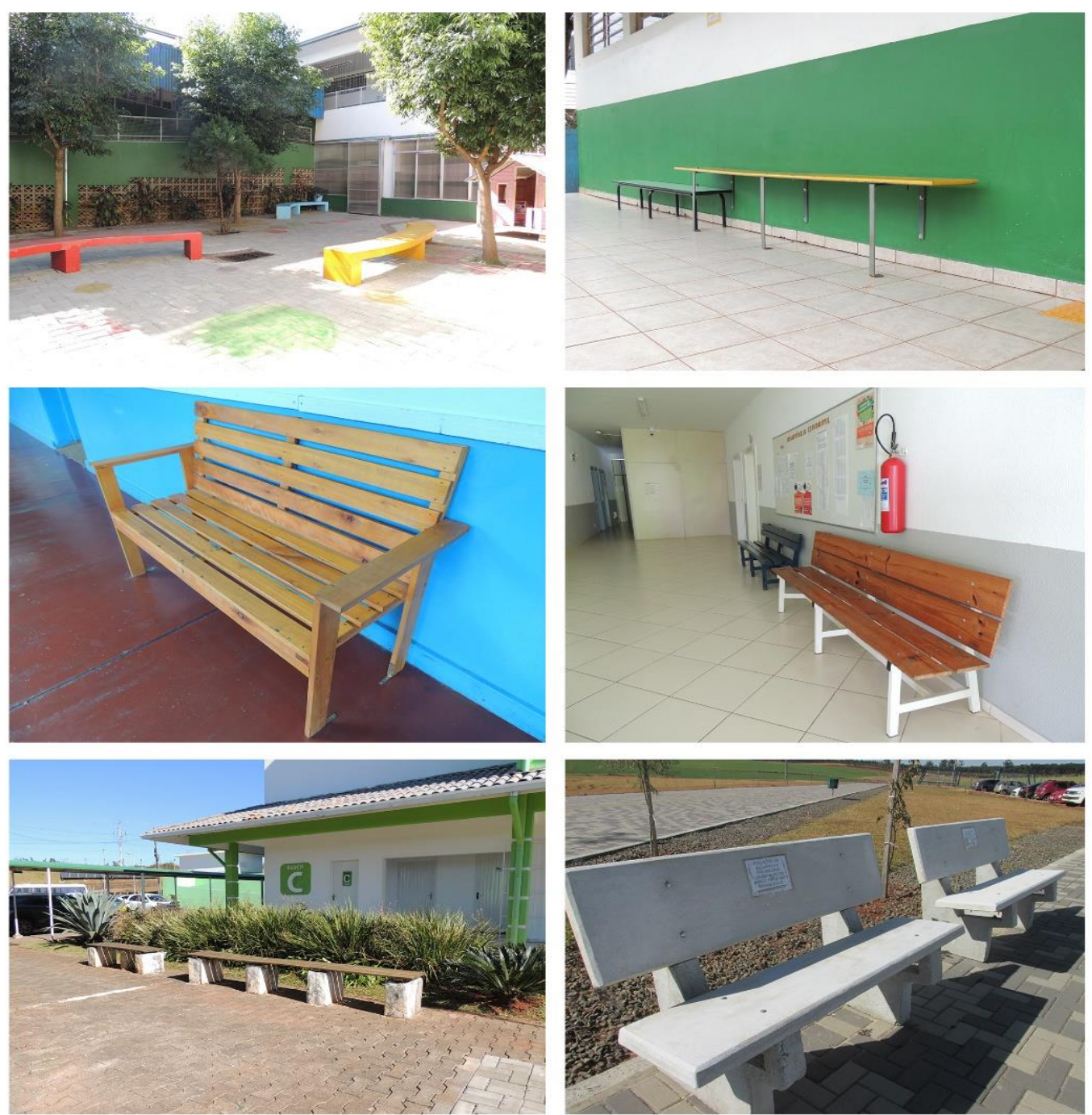

Fonte: Material de pesquisa, 2019.

Nota: Na sequência temos, respectivamente, EI1, EI2, EF1, EF2, ES1 e ES2. 
Durante as visitas, percebemos que os bancos das instituições possuem algo em comum. Muitos deles estão pregados no chão ou são feitos de concreto. Na EI1 não visualizamos nenhum banco, os locais destinados às crianças têm tapetes e cadeiras pequenas para que elas se organizem como quiserem. A EI2 não é tão diferente, porém, em um espaço aberto, encontramos bancos de concreto que não possibilitam a sua locomoção. Na EF1 encontramos bancos de madeira, livres para o deslocamento, mas também bancos pregados na parede e no chão. Na EF2 os bancos de madeira são pregados no chão. Na ES1 há bancos de concretos, bancos móveis e grandes almofadas. Na ES2, todos os bancos são de concreto, pesados e sem possibilidade de movimentação.

Pastoriza e Pino (2015, p. 307) alegam que "os muros que delimitam o espaço escolar também servem de sintagma de uma série de outros investimentos e espaços que possibilitam a circulação de um poder disciplinar". Esses outros investimentos ficam evidentes quando os bancos, destinados ao uso dos estudantes, são pregados ou colados o chão. Quando a escola não possibilita a movimentação dos seus bancos, está exercendo seu poder disciplinar, e garantindo a disciplina dos estudantes, garantindo que cada um ocupe o seu espaço, o espaço já organizado e devidamente destinado a esses sujeitos.

Conforme posto anteriormente, como definiu Comenius (2011), a escola precisa manter sua ordem, estar sempre organizada. Os bancos que fotografamos na pesquisa reforçam essa disciplinarização na escola. Pois, até mesmo nos locais de "intervalo", "recreio" ou "momento de convívio" os estudantes estão submetidos ao poder disciplinar, à uma situação em que não possuem formas próprias de ocupar o lugar, pois os bancos são engessados, fixados no chão. A respeito desse aspecto, Pastoriza e Pino (2015, p. 308) afirmam que

[...] essas forças se compõem num sistema o qual se engendra e se reforça, pois se os corpos são singularizados no exercício do poder disciplinar, se a ação sobre esses sujeitos implica um sistema preciso de comando que se estenda a todos, é necessária também uma especificação temporal que possibilitará uma organização na qual essas ações se desenvolverão. Sucessão de aulas, umas após as outras; controle do tempo de início, intervalo e final dos trabalhos; regulação dos momentos de descanso e de atividades, seja de professores, de alunos ou do corpo diretivo.

A escola, como um lugar planejado e bem organizado, nos ensina que a bagunça não faz bem, que não é algo positivo. Aprendemos a temer a bagunça, a sentir aversão por ela e a acreditar que a escola deve ser organizada e silenciosa, porque "sempre nos ensinaram que a ordem e o silêncio eram irmãos" (FERRAREZI JR., 2014, p. 15). Portanto, nos tornamos uma sociedade disciplinar. A sociedade disciplinar que Foucault (1987, p. 179) elucidou ser criada "no exercício cotidiano da vigilância, num panoptismo". Mas, o que podemos fazer para fugir desse controle disciplinar? Se os sujeitos crescem dentro desses espaços escolares e constituem-se em meio a essa relação poder-saber, como constituem-se sujeitos capazes 
de produzir poderes contrários? Como os sujeitos podem resistir a esses processos e ser autônomos? Sílvio Gallo (2004, p. 94) ajuda a responder essas perguntas ao pensar que

Se a escola tem sido, assim como o exército, um dispositivo disciplinador, ela é também um espaço social onde se exercem contrapoderes. [...] na relação pedagógica o aluno não é um mero paciente, mas é também um agente de poder, o que deve levar-nos a repensar todo o 'estrategismo pedagógico' do qual algumas vezes somos vítimas, outras vezes somos sujeitos (grifos meus).

Apesar de nossas escolas assemelharem-se com as prisões, não são a mesma instituição. Nossos estudantes não vivem suas vidas inteiras dentro desses espaços escolares, eles entram em contato com outros espaços, poderes, discursos e valores. Aprendem, como comprovou Foucault (1985), a produzir a si mesmos, a relacionar-se com a cultura. As instituições de educação formal, sejam elas de Educação Básicas ou Superior, são criadas para os estudantes, destinam-se a eles. Desta forma, o estudante é capaz de exercer poder suficiente para modificar esses espaços e suas regras disciplinares, é capaz de reivindicar instituições mais adequadas e menos fechadas, menos controladoras, menos disciplinares.

\section{Considerações finais}

Essa pesquisa foi iniciada com a motivação de compreender como as escolas contemporâneas estão configuradas e como o espaço escolar exerce poder disciplinar sobre os corpos dos escolares. Para isso, realizamos um estudo qualitativo em seis instituições formais de educação do município de Chapecó, região oeste de Santa Catarina. O impulso para investiga-los se deu pela vontade de questionar os espaços educativos que sempre frequentamos, que parecem engessados e que pouco são problematizados. Para entender quais foram as influências para a criação e organização de nossas escolas, estudamos a obra de Comenius (2011). Compreendendo que o conjunto de técnicas desenvolvidas pelo autor, em 1657, ainda é utilizado (mesmo que inconscientemente) na estruturação, organização e ação pedagógica das escolas contemporâneas.

As fotografias colocadas em sequências, separadas por espaços, possibilitou a visualização das semelhanças e das diferenças arquitetônicas e de composição física dos ambientes formais de ensino e de aprendizagem. As fotos dos espaços externos às salas de aulas, destinados aos estudantes e suas atividades "mais livres", evidenciam como as instituições de educação mantêm a ordem nos seus diferentes espaços, organizando de maneira que tais locais submetam os estudantes ao poder disciplinar, ao controle do adulto.

As referências bibliográficas utilizadas, em diálogo com a descrição das imagens e a legislação nacional, possibilitaram perceber a estrutura arquitetônica escolar como ferramenta para o exercício do poder disciplinar, capaz de moldar os corpos e as mentes daqueles que circulam nesse ambiente. Há nos 
espaços escolares estudados um poder disciplinar sendo exercido, que pode ser contrariado pelos indivíduos que ocupam esses espaços, pois eles também exercem poder.

Por fim, concluímos que a arquitetura dos espaços escolares é muito semelhante. As instituições de ensino seguem um padrão arquitetônico que não aparece na legislação, mas que é reproduzido constantemente. Esses espaços estão organizados de acordo com uma instrução desenvolvida na Idade Moderna. A arquitetura e a ordem escolar são mantidas, reproduzidas, em nome da segurança, o que faz com que a escola que frequentamos apresente a mesma arquitetura da época em que nossos pais a frequentaram e nossos filhos se depararão com essa mesma estrutura, desconsiderando as mudanças entre as distintas gerações.

\section{Referências}

BÁNOVČANOVÁ, Z; MASARYKOVÁ, D. The Docile Body - Reflecting the School. Journal of pedagogy, v. $5, \quad$ n. 2, p. 251-264, nov. 2014. Disponível em: https://www.degruyter.com/downloadpdf/j/jped.2014.5.issue-2/jped-2014-0012/jped-2014-0012.pdf.

Acesso em: 18 dez. 2019.

BRASIL. Constituição da República Federativa do Brasil. Brasília: Casa civil, 1988. Disponível em: http://www.planalto.gov.br/ccivil_03/Constituicao/Constituicao.htm. Acesso em: 19 out. 2019.

BRASIL. Lei $n^{\circ}$ 9.394, de 20 de dezembro de 1996 - estabelece as Diretrizes e Bases da Educação Nacional. Brasília: Casa civil, 1996. Disponível em: http://www.planalto.gov.br/ccivil_03/LEIS/L9394.htm. Acesso em: 17 out. 2019.

BRASIL. Ministério da Educação. Indicadores da Qualidade na Educação Infantil. Brasília: MEC/SEB, 2009a. Disponível em: http://portal.mec.gov.br/dmdocuments/indic_qualit_educ_infantil.pdf. Acesso em: 26 ago. 2019.

BRASIL. Ministério da Educação. Subsídios para credenciamento e funcionamento de instituições de educação infantil. Brasília: MEC, 1998. v. 2. Disponível em: http://portal.mec.gov.br/seb/arquivos/pdf/volume_II.pdf. Acesso em: 28 ago. 2019.

BRASIL. Resolução $n^{o}$ 4, de 13 de julho de 2010 - define Diretrizes Curriculares Nacionais Gerais para a Educação Básica. Diário Oficial da União, Brasília: MEC, 2010. p. 824-828. Disponível em: https://www.jusbrasil.com.br/diarios/DOU/2010/07/14. Acesso em: 06 out. 2019.

BRASIL. Resolução $n^{o}$ 5, de 17 de dezembro de 2009 - fixa as Diretrizes Curriculares Nacionais para a Educação Infantil. Brasília: Conselho Nacional de Educação, 2009b. Disponível em: http://portal.mec.gov.br/index.php?option=com_docman\&view=download\&alias=2298-rceb00509\&category_slug=dezembro-2009-pdf\&Itemid=30192. Acesso em: 25 ago. 2019.

CAMPOS, M. M. Critérios para um atendimento em creches que respeite os direitos fundamentais das crianças. 6. ed. Brasília: MEC, SEB, 2009. Disponível em: http://portal.mec.gov.br/dmdocuments/direitosfundamentais.pdf. Acesso em 27 ago. 2019.

COMENIUS. Didática Magna. Tradução Ivone Castilho Benedetti. 4. ed. São Paulo: Editora WMF Martins Fontes, 2011. 
ESCOLANO, A. A arquitetura como programa. In: FRAGO, A. V.; ESCOLANO, A. Currículo, espaço e subjetividade: arquitetura como programa. 2. ed. Rio de Janeiro: DP\&A, 2001. p. 26-47.

FARIA, A. B. G. Por outras referências no diálogo arquitetura e educação: na pesquisa, no ensino e na produção de espaços educativos escolares e urbanos. Em Aberto, v. 25, n. 88, p. 99-111, 2012. Disponível em: http://emaberto.inep.gov.br/index.php/emaberto/article/view/2588/0. Acesso em: 22 set. 2019.

FERARREZI JR., Celso. Pedagogia do silenciamento: a escola brasileira e o ensino de língua materna. 1. ed. São Paulo: Parábola Editorial, 2014.

FOUCAULT. História da sexualidade I: A vontade de saber. Tradução Maria Thereza da Costa Albuquerque e J. A. Guilhon Albuquerque. 23. ed. Rio de Janeiro, Edições Graal, 2013.

FOUCAULT. História da sexualidade III: o cuidado de si. Tradução Maria Thereza da Costa Albuquerque. Rio de Janeiro: Edições Graal, 1985.

FOUCAULT. Microfísica do poder. 28. ed. Rio de Janeiro: Paz e Terra, 2014.

FOUCAULT. Vigiar e punir: nascimento da prisão. Tradução Raquel Ramalhete. 30. ed. Petrópolis, RJ: Vozes, 1987.

GALLO, Sílvio. Repensar a educação: Foucault. Educação \& Realidade, Porto Alegre, v. 29, n.1, p.79-97, jan/jun. 2004. Disponível em: https://seer.ufrgs.br/educacaoerealidade/article/view/25420. Acesso em: 02 maio 2019.

INSTITUTO NACIONAL DE ESTUDOS E PESQUISAS EDUCACIONAIS ANÍSIO TEIXEIRA. Cartilha Saeb 2019. Brasília: Inep/MEC, 2019a. Disponível em: http://portal.inep.gov.br/informacao-dapublicacao/-/asset_publisher/6JYIsGMAMkW1/document/id/6734620. Acesso em: 16 out. 2019.

INSTITUTO NACIONAL DE ESTUDOS E PESQUISAS EDUCACIONAIS ANÍSIO TEIXEIRA. Instrumento de avaliação institucional externa: Presencial e a distância - Credenciamento. Brasília: Inep/MEC, out. 2017a. Disponível em: http://download.inep.gov.br/educacao_superior/avaliacao_institucional/instrumentos/2017/IES_credencia mento.pdf. Acesso em: 15 out. 2019.

INSTITUTO NACIONAL DE ESTUDOS E PESQUISAS EDUCACIONAIS ANÍSIO TEIXEIRA. Prova Brasil: questionário da escola, 2017b. Disponível em: http://download.inep.gov.br/educacao_basica/saeb/aneb_anresc/quest_contextuais/2017/questionario_esc ola_2017.pdf. Acesso em: 16 out. 2019.

INSTITUTO NACIONAL DE ESTUDOS E PESQUISAS EDUCACIONAIS ANÍSIO TEIXEIRA. Sistema de Avaliação da Educação Básica. Portal Inep: 2019b. Disponível em: http://portal.inep.gov.br/web/guest/educacao-basica/saeb. Acesso em: 16 out. 2019.

KÜNZLE, M. R. C. Os espaços escolares e a construção de um programa antidisciplinar. Roteiro, v. 32, n. 2, p. 221-244, 2007. Disponível em: https://portalperiodicos.unoesc.edu.br/roteiro/article/view/349. Acesso em: 30 set. 2019.

NARODOWSKI, M. Comenius \& a educação. 2. ed. Belo Horizonte: Autêntica, 2006.

PASTORIZA, Bruno dos Santos; PINO, José Claudino Del. Para Falar de Disciplina, Corpos e Conhecimentos Entre os Muros da Escola. Revista Eletrônica de Educação, v. 9, n. 1, p. 301-317, 2015. Disponível em: http://www.reveduc.ufscar.br/index.php/reveduc/article/viewFile/1178/396. Acesso em: 17 out. 2019.

RIBEIRO, S. L. Espaço escolar: um elemento (in)visível no currículo. Sitientibus, n. 31, p. 103-118, 2004. Disponível em: http://www2.uefs.br/sitientibus/pdf/31/espaco_escolar.pdf. Acesso em: 18 out. 2019. 
Recebido em: 24/03/2020

Aceito em: 07/07/2020

\section{Notas}

i Mestranda no Programa de Pós-Graduação em Educação, pela Universidade Federal da Fronteira Sul. E-mail: carminattii.victoria@gmail.com Rio Grande do Sul ORCID: http://orcid.org/0000-0002-6829-5672

ii Doutora em Educação. Docente no Programa de Pós-Graduação em Educação, na Universidade Federal da Fronteira Sul. Email: patricia.graff@uffs.edu.br Rio Grande do Sul ORCID: http://orcid.org/0000-0002-3315-2401 